\title{
空中超音波のコインシデンス効果を利用するヒートシール瑕疵の非接触検出
}

\author{
森 健太 ${ }^{* 1}$, 井上 卓見 ${ }^{* 2}$, 門脇 廉 ${ }^{* 3}$
}

\section{Non-contact detection of heat seal defect using the coincidence effect of airborne ultrasound}

\author{
Kenta MORI $^{* 1}$, Takumi INOUE ${ }^{* 2}$ and Ren KADOWAKI ${ }^{* 3}$ \\ ${ }^{* 1}$ Department of Mechanical Engineering, Graduate School of Engineering, Kyushu University \\ 744 Motooka, Nishi-ku, Fukuoka 819-0395, Japan

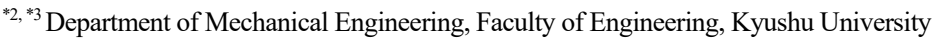 \\ 744 Motooka, Nishi-ku, Fukuoka 819-0395, Japan
}

Received: 8 October 2019; Revised: 19 January 2020; Accepted: 6 May 2020

\begin{abstract}
Heat sealing is a packaging technique by means of welding of seal materials with heating and compression, and is widely used for hermetic seal of foods and medical supplies. However, a defect of the heat sealing, for example a "pinhole", caused by small wrinkle on the sealing film or jamming by contaminants occasionally arises. In order to enhance the reliability of heat seal products, this study proposes a nondestructive technique to detect such a small defect in the heat seal by utilizing coincidence effect of airborne ultrasound. In the proposed method, a bending wave with sufficient amplitude is excited by the coincidence effect, and this bending wave appears as a traveling wave on the heat seal. This traveling wave is sensitive to the defect in heat seal and shows apparent phase lags compared with defectless heat seal. Therefore, defect in the heat seal is detectable by observation of the phase lags in the traveling wave. Arrangement of ultrasound transmitter and receiver is important for the proposed technique in order to observe the phase lags efficiently. Traveling wave plays an important role to detect the defect in heat seal, so that the airborne ultrasound inspection without the coincidence effect is unavailable because the traveling wave is not generated. Validity of the proposed technique is demonstrated through experiments and numerical simulations.
\end{abstract}

Keywords : Diagnostics, Signal processing, Ultrasound, Heat sealing, System identification, Coincidence effect

\section{1. 緒言}

ヒートシールとは加圧・加熱により複数の熱可塑性樹脂フィルムの面同士を溶着する封入法であり, 図 1 に示 すレトルト食品や医薬品をはじめとする様々な製品の包装に用いられる. しかし，被溶着材料の小さなシワに起 因するピンホールの発生や，溶着面への異物混入等の瑕疵によりヒートシールの特長である密封性が損なわれる ことがある．図 2 はピンホールの一例である．そのため，これらの瑕疪を出荷前にできるだけ簡便な方法で検出 して製品の品質を確保したい要求がある. 瑕疵検出にはいくつかの試みが行われているが，同時に課題も指摘さ れている. 温度画像解析(D’huys et al., 2016)は簡便な方法である反面, 小さな異物を検出できず検出精度に乏しい. 質量分析により封入ガスの漏れを調べる手法(Axelson and Cavlin, 1991)は高精度であるものの，検査が長時間に及 ぶため製造ライン上での全数検査には適さない. 電流を被検査物に通寸手法(Axelson et al., 1990, Larsson et al., 1997, Hsu and Chang, 2007)は電流值から微小な瑕疪を検出でき，水中超音波による方法(Ozguler et al., 1998, Pascall et al., 2002, Ayhan and Zhang, 2003)は高振動数の超音波を利用できるため精度よく瑕疪を検出できるが，両者とも被検査 物を液体中に沈める必要があり簡便性や衛生面からは望ましくない. 偏光応力解析(Barnes et al., 2012)は効率的に ピンホールを検出できるものの光が透過しない被検查物には適用できず，高電圧電極を包装に接触させる方法 (Song et al., 2014)やテラヘルツ電磁波を利用した方法(森田他，2005)は，ピンホールの空隙が内容物で満たされて

No.19-00381 [DOI:10.1299/transjsme.19-00381], J-STAGE Advance Publication date : 15 May, 2020

*1 正員，九州大学大学院 工学府（T819-0395 福岡県福岡市西区元岡 744）

*2 フェロー，九州大学大学院 工学研究院

*3 正員, 九州大学大学院 工学研究院

E-mail of corresponding author: mori@dynamic.mech.kyushu-u.ac.jp 
いれば高精度で瑕疪を検出できるが，そうでない場合は検出感度が不十分となる。このようにヒートシールの瑕 疵検出には未だ課題があり，これらを解決する方法が望まれている.

本研究ではこれらの課題に対し空中超音波を用いた瑕疪検出法を提案する. 空中超音波は非接触検査が可能で あり，衛生面において大きな利点となるとともに検查機器も小型で容易に取り扱える．一方，空中超音波は加振 力が弱く, 単に検查体に投射しただけでは微小な层疪を検出できない. そこで本研究ではコインシデンス効果を 利用した効果的な瑕疪検出方法を提案する．コインシデンス効果とは，空中音波が特定の角度で板状の物体に入 射する場合にその物体の曲げ振動が著しく増幅する現象であり，無限板での理論(Cremer, 1942)や有限円板で共振 も考慮した理論(玉井他, 1987)などが知られている. 主に壁の遮音性を悪化させる現象として扱われてきたが, 本 研究では十分な振動を被検查物に与える手段としてコインシデンス効果を利用し, 微小な瑕疪検出を試みる.こ こでは提案手法の実現可能性を調べるため，フィルム状のヒートシールを対象として人工的に作成したピンホー ルの検出を行う. 実験結果から，コインシデンス効果により増大した曲げ振動の位相がピンホールの有無により 変化することを示し，この変化に着目することでピンホール状の瑕疪が検出可能であることを示す．さらに，瑕 疵部であるピンホールを局所的な剛性低下としてモデル化した数值シミュレーションを行い，実験と同様の現象 を再現し，提案した手法の有効性，妥当性を明らかにする.

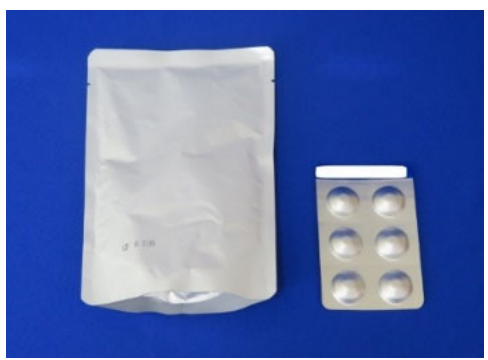

Fig. 1 Examples of heat seal. Pouch container for food and medicine.

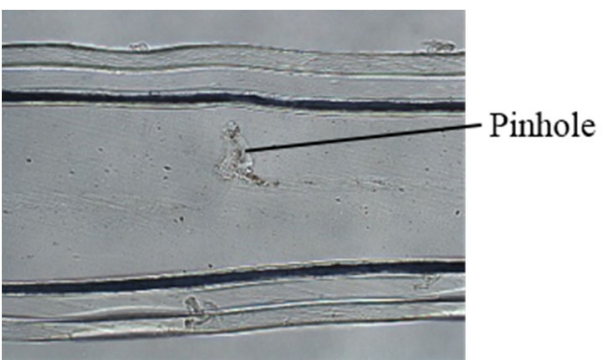

Fig. 2 Sectional view of heat seal. Defect of pinhole is observed.

\section{2. 空中超音波のコインシデンス効果とヒートシールの瑕疵検出}

通常のコインシデンス効果は板状の壁などに入射する可聴域の音波に起因する現象であり，本研究で扱う薄い フィルム状のヒートシールに空中超音波によって励起されるコインシデンス効果とは量的に異なる. しかしなが ら, 両者には同一の力学が成り立つため, 従来のコインシデンス効果の理論は本研究でも有効であり, これを踏 まえた議論を行う。空中超音波は空気の粗密波であり，図３のように正圧部（橙色）と負圧部（水色）が進行方 向に交互に現れる. 図 3(a)に示寸フィルム状のヒートシールへの垂直な超音波入射では，正圧と負圧が交互に作 用して波面と平行にシール部が振動する. 一方，図 3(b)に示す斜めの超音波入射では，波面の傾きによりフィル ム上に正圧部と負圧部が交互に並び曲げ変形が生じる．超音波の進行に伴って正圧部と負圧部はフィルムに沿っ て一方向に移動するため, 曲げ変形も移動し曲げ波となる. この移動速度 $c_{a}$ は, 空気中での音速 $c$, 入射角度 $\theta$ から $c_{a}=c / \sin \theta$ と表される. 一方，曲げ波にはフィルムの特性等から定まる固有の伝播速度 $c_{b}$ が存在する.

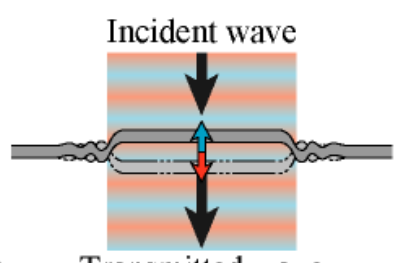

(a)

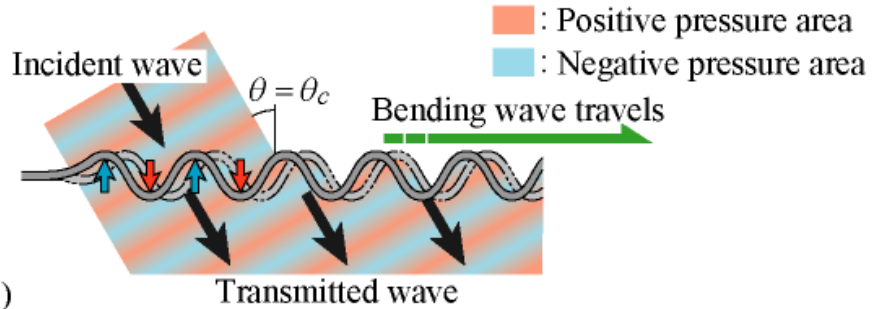

Fig. 3 (a) Vertical incidence of airborne ultrasound generates vibration of film only in the incident area and transmitted wave is also generated only in the incident area. (b) Oblique incidence of airborne ultrasound, where incident angle $\theta$ is coincidence angle $\theta_{c}$, excites bending wave of large amplitude on the film, and bending wave travels in one direction. Transmitted wave also propagates along with the bending wave. 


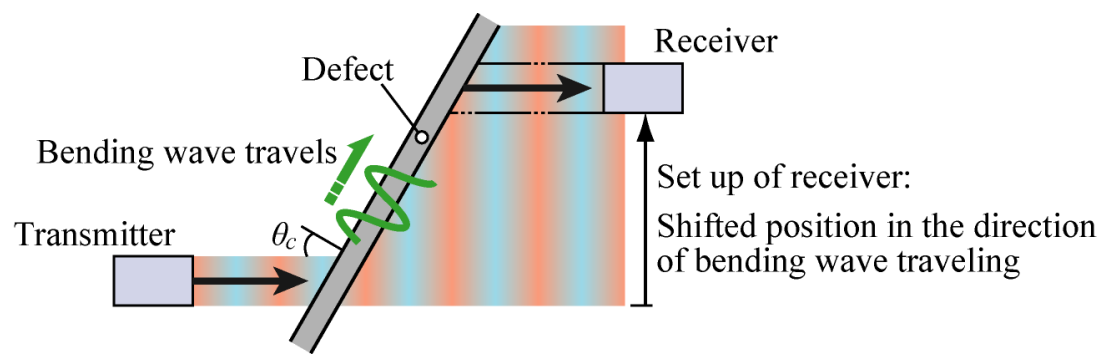

Fig. 4 Proposed method to detect a defect of heat seal film. Coincidence effect is generated by oblique incidence of coincidence angle $\theta_{c}$. Receiver is set up at shifted position in the direction of wave propagation. In the case that defect lies between transmitter and receiver, transmitted wave via defect is received.

図 3(b)のフィルムの曲げを奥行き方向一様としてはりの曲げとみなせば, 固有伝播速度 $c_{b}$ はヒートシール部の曲 げ剛性 $E I$, 断面積 $A$, 密度 $\rho$, 曲げ波の角振動数 $\omega$ を用いて $c_{b}=\sqrt[4]{E I \omega^{2} / \rho A}$ と表される. 音圧の移動速度 $c_{a}$ と 曲げ波の固有伝播速度 $c_{b}$ が一致する角度で超音波が入射すると, 固有伝播速度を持つ曲げ波を励起するように 音圧が作用して振幅が大きく増加する．この現象がコインシデンス効果である(Cremer, 1942). コインシデンス効 果を起こす超音波の入射角度 $\theta_{c}$ （コインシデンス角度 $\theta_{c}$ と呼ぶ）は $c_{a}=c_{b}$ から次のように得られる.

$$
\theta_{c}=\sin ^{-1}\left(\frac{c}{\sqrt[4]{E I \omega^{2} / \rho A}}\right)
$$

コインシデンス効果には図 3(b)に示すように曲げ波が空中超音波の入射領域を越えて一方向に伝播する特徴があ り, 本研究ではこれらの特徴を利用したヒートシールの検查法を提案する. なお，入射角度がコインシデンス角 度の近傍でない場合, 図3(a)の垂直入射と同様に曲げ波は超音波が入射する部分以外にはほとんど伝播しない.

提案手法では，図 4 のように送信用探触子（以降，送信機と呼ぶ.）の入射角度をコインシデンス角度 $\theta_{c}$ に調 節してコインシデンス効果を発生させるとともに, 受信用探触子 (以降, 受信機と呼ぶ.) を送信機の正面から曲 げ波の伝播方向に離して配置する．検出対象となる瑕疪は送信機と受信機の間にあるものとし，ヒートシールを 伝播して瑕疪を通過した曲げ波から放出される空中超音波を受信し瑕疪検出を試みる.

\section{3. ピンホール検出実験}

\section{$3 \cdot 1$ 実験対象と装置概要}

実験対象として, 図 5 に示寸長さ $100 \mathrm{~mm}$, 幅 $30 \mathrm{~mm}$, 厚さ $100 \mu \mathrm{m}$ の 2 枚のポリプロピレン（PP）フィルムを 中央部 $10 \mathrm{~mm}$ で帯状に溶着したヒートシール試験片を用いた. 溶着前のフィルム間に針金を挟み，溶着後に引き 抜くことで人工的にピンホールを作成し，検查対象の瑕疪とした．溶着後の全体の厚さは $200 \mu \mathrm{m}$ であり，ピン ホール径は針金の直径とほぼ等しいことを確認している，また，実験では試験片に張力を与えずに周囲 4 辺を治 具で把持し，把持状態での平面度は約 $0.1 \mathrm{~mm}$ であった. 試験片は 5 個作成し，それぞれに対して実験を行った.

実験装置は図 4 の概略に従い図 6 のように設定した。図中の重力方向が示寸通り，送受信機や試験片は紙面の

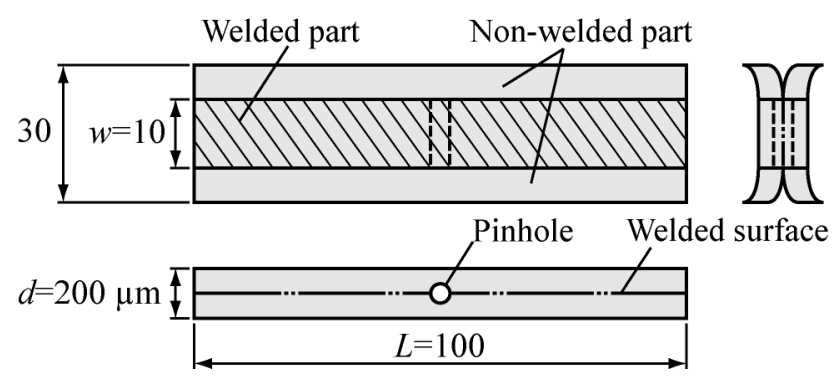

Fig. 5 Overview of sample. Artificial pinhole is located in center of welded part. 


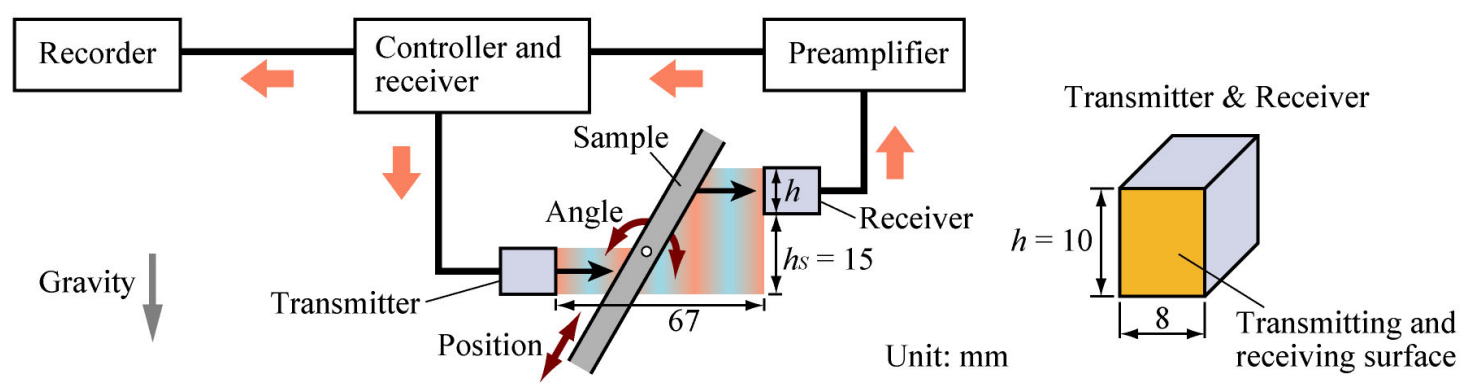

Fig. 6 Outline of experimental apparatus. Tilting angle and position of heat seal sample is adjustable. Input signal is sent to transmitter from controller, then airborne ultrasound is projected to heat seal sample. Transmitted ultrasound via bending wave on heat seal is received at shifted position from the front place of transmitter. Received signal is amplified and recorded after filtering of high and low frequency components.

上から下へ重力が作用する姿勢で設置した，ただし，試験片が小さくて軽いため，重力の影響はほとんどないと 考えられる. 送信機と受信機は同一仕様の空中超音波用探触子 (AR0.8K7×10N-TX, ジャパンプローブ) であり， 送信面・受信面は $8 \mathrm{~mm} \times 10 \mathrm{~mm}$ の長方形平面である. 送受信機は図 6 に示すように送受信面が平行な状態で, 超音波の送信方向に $67 \mathrm{~mm}$ ，かつ垂直方向に $15 \mathrm{~mm}$ 離れた位置に配置した. コントローラ（JPR-10CN，ジャパン プローブ）からの入力で送信機の固有振動数と一致する $620 \mathrm{kHz}$ の空中超音波を発信させた．試験片の傾斜角

(Angle) と位置 (Position) は治具によって調節した. 受信波はプリアンプ（PR-60A，ジャパンプローブ）で増幅 された後, コントローラのフィルタ機能で $200 \mathrm{kHz}$ 以下と $1000 \mathrm{kHz}$ 以上の振動数成分が除去され，オシロスコー プ（DPO4032, Tektronix）に記録された.

図 5,6 の試験片と装置で傾斜角を $0.1 \mathrm{deg}$.ずつ変化させながら超音波を投射すると，受信超音波の振幅は 37.5 deg.で最大となった. そのため, コインシデンス角度は $\theta_{c}=37.5 \mathrm{deg}$.であるとした. このときの空中音速は実験時 の雰囲気温度 $26{ }^{\circ} \mathrm{C}$ ので $c=347.1 \mathrm{~m} / \mathrm{s}$ であった.

また，後述する数值シミュレーションでは実験と同様の幾何学的配置でコインシデンス効果が発生するとして 実験結果との比較を行う. そのため, 空中音速 $c=347.1 \mathrm{~m} / \mathrm{s}$, 超音波の振動数 $\omega / 2 \pi=620 \mathrm{kHz}, \mathrm{PP}$ フィルムの密 度 $\rho=902 \mathrm{~kg} / \mathrm{m}^{3}$ (高分子学会, 1986) 用いて $\theta_{c}=37.5 \mathrm{deg}$. となるように曲げ剛性 $E I$ を $E I=14.0 \times 10^{-6} \mathrm{~N} \cdot \mathrm{m}^{2}$ とした. これに対して, PP フィルムの縦弹性係数 $1.37 \mathrm{GPa}$ (高分子学会, 1986)から試験片の曲げ岡性を $9.1 \times 10^{-6} \mathrm{~N} \cdot \mathrm{m}^{2}$ と 見積もることもできるものの，加熱と溶融を経ている試験片がこの值をとっているかは明らかでない，そこで， 以後は試験片の曲げ岡性として上記の $E I=14.0 \times 10^{-6} \mathrm{~N} \cdot \mathrm{m}^{2}$ を用いる．なお，この曲げ剛性と実験時の各パラメー タを式(1)に代入して得られるコインシデンス角度は $36.3 \mathrm{deg}$.であることから, 数值シミュレーションによる推定 值も実態から大きくは異なっていないと考えられる.

\section{$3 \cdot 2$ 提案手法の有効性検証}

まず，比較的大きな $100 \mu \mathrm{m}$ 径のピンホールを対象として提案手法の有効性を確認する. ピンホールと送受信 機の相対的な位置関係は図 7 に示す 3 通りとし, ピンホールが受信機上端より約 $5 \mathrm{~mm}$ 上側にある場合を Case $\mathrm{A} 1$ ，送受信機の中間にある場合を Case A2，送信機下端より約 $5 \mathrm{~mm}$ 下側にある場合をCase A3 とした. 一例とし て，5個中の 1 つの試験片について Case A1 A3 の位置で測定した受信信号を図 8 に示す. 図 8(a)は波形の全体 図, 図 8(b)は一部の拡大図であり, 横軸はコントローラの送信時刻を基準とした経過時間, 縦軸は受信信号の電 圧值を示寸．図 8(b)から，Case A1 とCase A3 の波形はほぼ同じ位相を持つ一方，Case A2 の波形は Case A1,A3 か

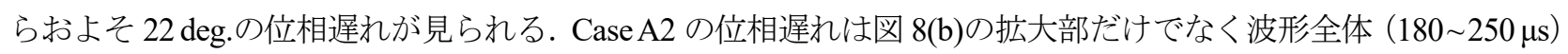
に見られている，そこで，波形全体の位相差を見る指標として受信波を複素フーリエ変換し，主たる振動数であ る $620 \mathrm{kHz}$ 成分の位相 $\phi_{620 \mathrm{k}}$ に着目寸る. 受信波の $620 \mathrm{kHz}$ の複素フーリエ成分を $U_{620 \mathrm{k}}$ とすると,

$$
\phi_{620 \mathrm{k}}=\tan ^{-1}\left[\operatorname{Im}\left(U_{620 \mathrm{k}}\right) / \operatorname{Re}\left(U_{620 \mathrm{k}}\right)\right]
$$


と表される.ただし，任意の時刻を基準に求めた受信波の位相 $\phi_{620 \mathrm{k}}$ は実験条件によって様々な值をとり得る.こ れに対して, 提案手法では位相の絶対值よりもCase 間の位相差に興味がある. また, 予備的に Case A1, A3 より もピンホールから離れた正常部を測定しても，Case A1，A3 と同程度の位相となることがわかっている.すなわ ち, Case A1，A3 での位相の值が当該試験片の正常部の位相を表すと考えられる．そこで，本稿では Case A1 と Case A3 の位相の平均值が 0 deg. となる位相シフト処理を各試験片のデータに対して施し，瑕疵による Case A2 の 位相遅れの有無を可視化する.

5 個すべての試験片について Case A1 A3 の位置で測定した受信波の $\phi_{620 \mathrm{k}}$ を図 9 に示す。この図では，すべて の試験片で Case A2 の $\phi_{620 \mathrm{k}}$ に Case A1, A3 から 20 30 deg.程度の明らかな位相遅れが見られる. すなわち, ピン ホールが空中超音波の送信機と受信機の間にある場合のみに受信波に明確な位相遅れが現れることがわかるまま た，ピンホールがない健全な試験片に対しては，すべての測定位置で $\phi_{620 \mathrm{k}}$ にはほとんど違いがなく，Case A2 の ような明瞭な位相遅れは現れなかった。これらの結果から, 送受信範囲内にピンホールがあれば受信波の位相に 明確な遅れが生じ，この性質に着目することでピンホールの有無を検出できる.

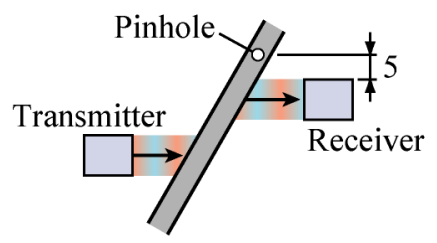

Case A 1

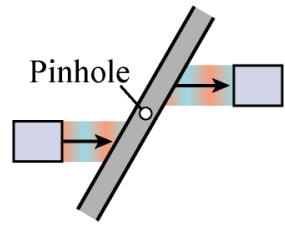

Case A2

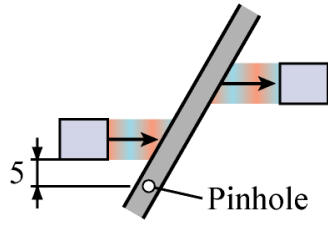

Case A3

Fig. 7 Relative positions of transmitter, receiver and pinhole in proposed method. Pinhole lies between transmitter and receiver only in Case A2.

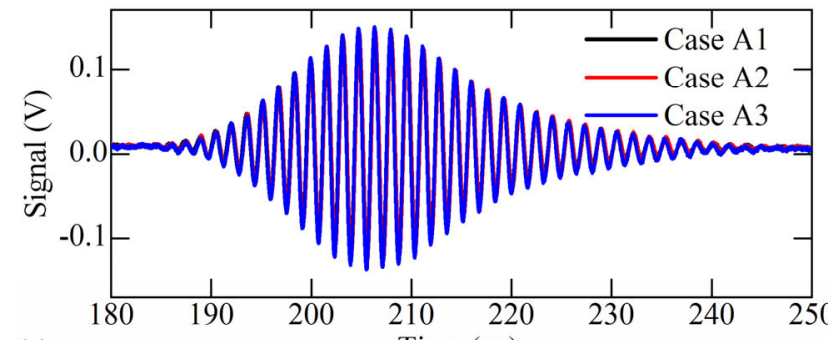

(a)
Time $(\mu \mathrm{s})$

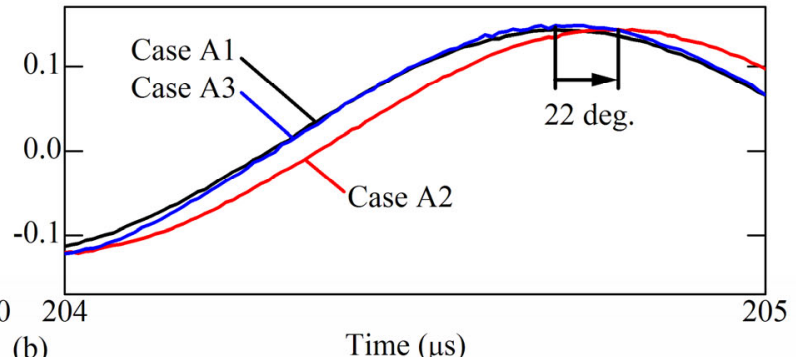

(b)

Time $(\mu \mathrm{s})$

Fig. 8 Experimental results of proposed method to heat seal sample with $100 \mu \mathrm{m}$ diameter pinhole. (a) Whole waveforms and (b) enlarged figure. Significant phase lag is observed only in Case A2, where pinhole lies between transmitter and receiver.

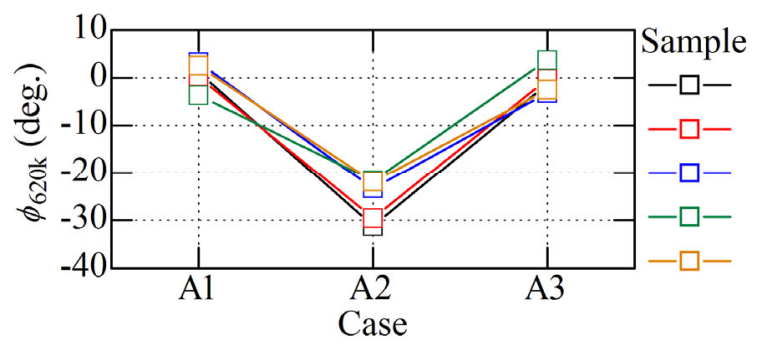

Fig. 9 Phase of dominant frequency component of received waveforms $\phi 620 k$ for all samples. Significant phase lags of $20 \sim 30$ degree are observed only in Case A2, where pinhole lies between transmitter and receiver, compared with Case A1 and A3. Pinhole can be detected by means of these characteristics.

次に，コインシデンス効果を利用しない垂直投射による検査法について検証する. 図 3(a)のように対象物に垂 直に投射された超音波は送信機に垂直な位置のみで観測されるため，送受信機とピンホールの相対的な位置関係 は図 10(a)に示す Case B1～B3 とした. Case B1，B3 は超音波の投射領域からそれぞれ上または下に約 5 mm 離れ 
た位置にピンホールが存在し，Case B2 のみ投射領域の中央部にピンホールが存在する．ピンホール径は同様に $100 \mu \mathrm{m}$ とした. 図 9 と同様に，す心゙ての試験片について受信波の $620 \mathrm{kHz}$ 成分の位相 $\phi_{620 \mathrm{k}}$ を図 10(b)に示す. 受 信波の $\phi_{620 \mathrm{k}}$ には Case B1 B3 による有意な位相差は見られない. 受信波形そのものにも Case B1 B3 による差異 は見られなかった。このように，コインシデンス効果を利用せず超音波を試験片に垂直に投射する方法では，比 較的大きな $100 \mu \mathrm{m}$ 径のピンホールでもまったく検出できないことがわかる.

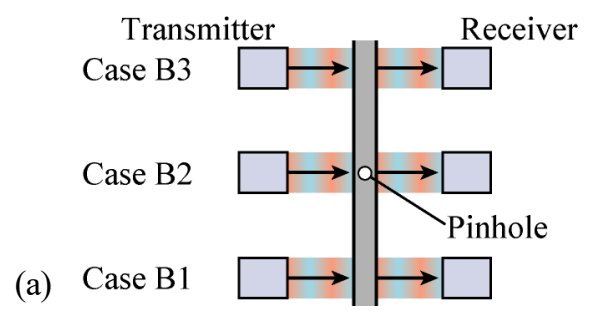

(b)

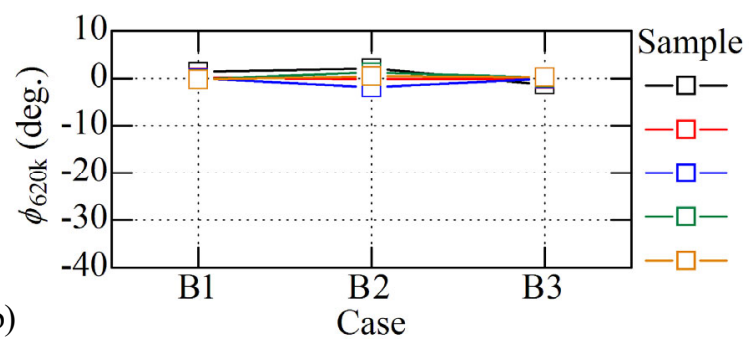

Fig. 10 (a) Relative positions of transmitter, receiver and pinhole in vertical ultrasound transmission. Pinhole lies within projection area only in Case B2. (b) No difference is observed in phase of $620 \mathrm{kHz}$ component of received waveforms $\phi 620 \mathrm{k}$ for all samples.

提案手法は，コインシデンス効果により発生した曲げ波がヒートシール内を一方向に伝播寸る特徵を利用して おり，受信波は送信機から曲げ波の伝播方向に離れた位置で受信される。この効果を検証するため，コインシデ ンス効果を発生させるものの, 図 11(a)に示すように受信機を送信機の正面に設置して受信波を測定した. ピンホ ール径は同様に $100 \mu \mathrm{m}$ とし, 送受信機とピンホールの相対的な位置は図 11(a)に示す Case $\mathrm{C} 1 \sim \mathrm{C} 3$ の 3 通りとし た. Case C1 では送受信機の上端より約 $5 \mathrm{~mm}$ 上側, Case C3 では送受信機の下端より約 $5 \mathrm{~mm}$ 下側にピンホール が存在し, Case C2 のみ超音波の投射領域の中央部にピンホールが存在する. 受信波の $620 \mathrm{kHz}$ 成分の位相 $\phi_{620 \mathrm{k}}$ を示す図 11(b)を見ると，すべての試験片で Case C2 の位相が Case C1,C3 から 7 10 deg.程度遅れていることがわ かる.この結果はコインシデンス効果を用いた斜めの投射が図 10 の垂直投射よりピンホールの検出に有効であ ることを示唆しているが，提案手法で得られた図 9 は更に大きな位相遅れを示している．したがって，斜めに投 射してコインシデンス効果を起こすのに加え，受信機を送信機の正面ではなく曲げ波の伝播方向に離して設置す る提案手法がピンホールの検出に有効であるとわかる.この理由は第 4 章の数值シミュレーションで考察する.

(a)



(b)

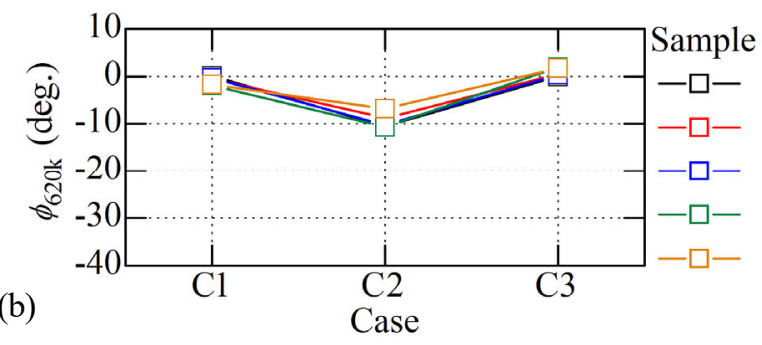

Fig. 11 (a) Relative positions of transmitter, receiver and pinhole. Although airborne ultrasound is projected at coincidence angle, receiver is located at the front position of transmitter. Pinhole lies within projection area only in Case C2. (b) Phase lags of $620 \mathrm{kHz}$ component $\phi_{620 \mathrm{k}}$ are observed in Case C2 for all samples, however the amount of phase lags are smaller than that of our proposed method (Fig. 9).

\section{$3 \cdot 3$ 小径ピンホールの検出}

3.2 節の結果から, コインシデンス効果による曲げ波伝播を利用する提案手法がヒートシール内のピンホール


どのピンホールの検出が要求される. そのため, まず $50 \mu \mathrm{m}$ 径のピンホールを持つ試験片に提案手法を適用した. 試験片は同様に 5 個作成し，それぞれに対して実験を行った．図７に示す Case A1 A3 の位置関係で実験を行っ 
た結果について， $620 \mathrm{kHz}$ 成分の位相 $\phi_{620 \mathrm{k}}$ を図 12(a)に示す.すべての試験片で Case A2 の $\phi_{620 \mathrm{k}}$ は Case A1, A3 か ら 9 17 deg. ほど遅れており, 提案手法によって $50 \mu \mathrm{m}$ 径のピンホールも検出可能である.

さらに $30 \mu \mathrm{m}$ 径のピンホールに対して同様の実験を行うと, 図 12(b)に示寸結果が得られた. この図 12(b)から は，Case A2 に位相遅れの現れない試験片が多いことがわかる．そのため，現時点では $30 \mu \mathrm{m}$ 径のピンホールの 検出精度は十分ではないと考えられる．これに対して，投射する超音波の高周波数化は検出精度を高めうること が後述の数值シミュレーションから示唆されている. また，コインシデンス効果は検査対象や雾囲気の温度, 対 象表面の平面度等に影響されるため，これらの影響を考慮した高精度な測定系を構築することで更なる検出感度 の向上が実現できると期待される.



(a)

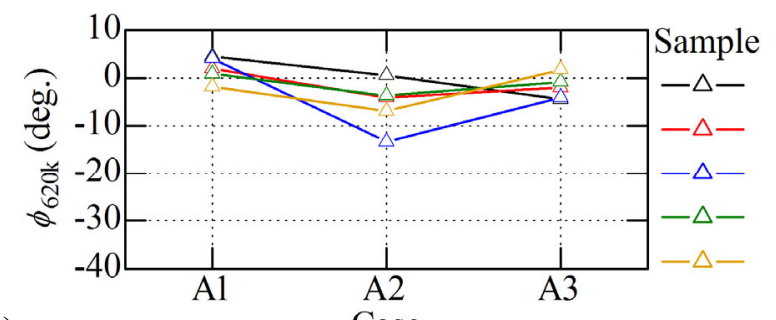

(b)

Case

Fig. 12 Experimental results with (a) $50 \mu \mathrm{m}$ diameter pinhole and (b) $30 \mu \mathrm{m}$ diameter pinhole by applying the proposed method, arrangement of transmitter and receiver is shown in Fig. 7. (a) Certain phase lags of $620 \mathrm{kHz}$ component $\phi_{620 \mathrm{k}}$ are observed for all samples in Case A2, where pinhole lies between transmitter and receiver. (b) Most of samples do not show definite phase lag in Case A2.

\section{4. 数值シミュレーション}

\section{$4 \cdot 1$ モデル化}

試験片に生じる曲げ波および受信超音波を再現する数值シミュレーションを行い，提案手法の有効性を裏付け る. 図 5 に示寸試験片の溶着部を, 長さ $L=100 \mathrm{~mm}$, 断面積 $d \times w=0.2 \mathrm{~mm} \times 10 \mathrm{~mm}$ の矩形断面はりとし, 図 13 に示すように長手方向に $n$ 等分した集中系としてモデル化した。系の両端および分割点を左端から順に

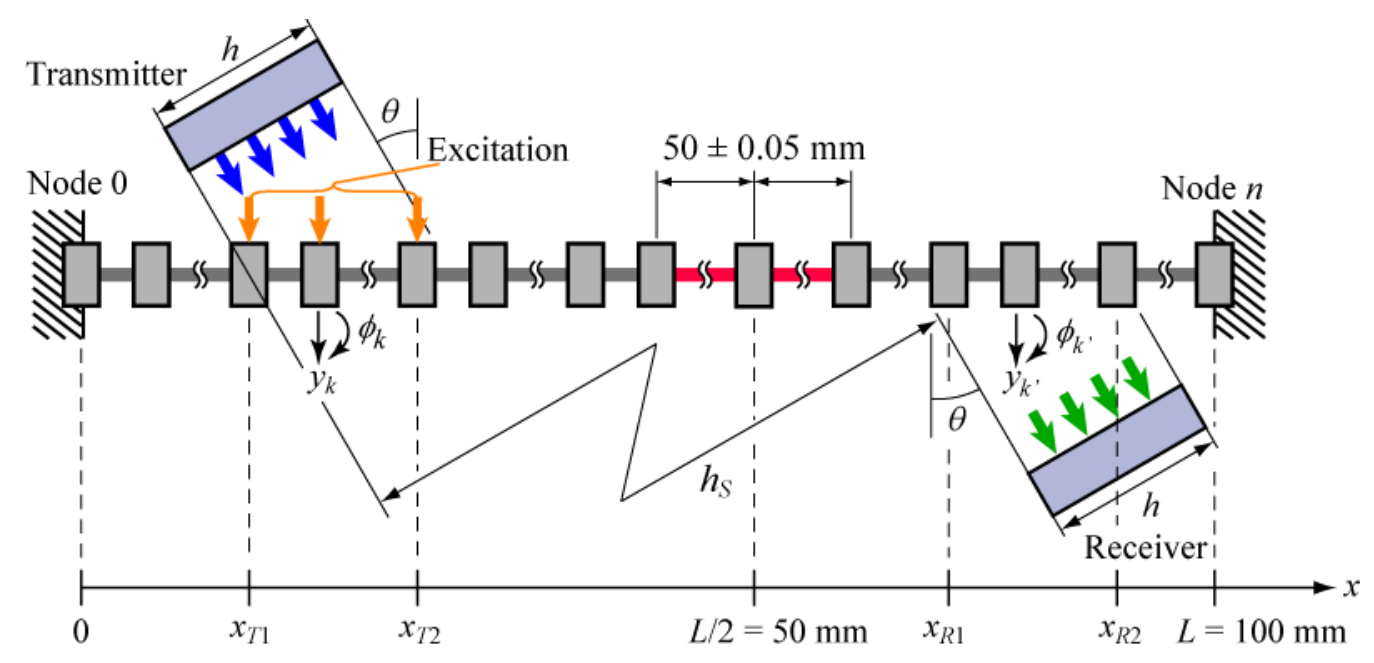

Fig. 13 Overview of lumped mass model for heat seal sample. Airborne ultrasound is projected at angle $\theta$ and the projected area between $x_{T 1}$ and $x_{T 2}$ is excited. Bending wave travels in the positive direction of $x$ and ultrasound wave from the area between $x_{R 1}$ and $x_{R 2}$ is received. Area of $x=50 \pm 0.05 \mathrm{~mm}$ is assumed to be defect and modeled as decrease of rigidity.

節点 $k=0,1,2, \cdots, n$ と呼び, 各節点における面内横変位 $y_{k}(t)(k=0,1,2, \cdots, n)$, 角変位 $\phi_{k}(t)$ を考える. ただし, 試験 片の両端は治具に固定されているため, 図 13 のように節点 0 と節点 $n$ は固定とし, $y_{k}(t), \phi_{k}(t)(k=1,2, \cdots, n-1)$ を変数とする $2(n-1)$ 自由度系とした. はりの左端を原点とする長手方向の $x$ 座標を設定し, ピンホール等の瑕疵 
部は試験片中央部 $x=L / 2=50 \mathrm{~mm}$ に設定した。ここでは $100 \mu \mathrm{m}$ 径のピンホールを想定して，厚さ $d=0.2 \mathrm{~mm} の$ 断面の中央に直径 $100 \mu \mathrm{m}$ の円柱状の欠損があるとし，これによる断面二次モーメントの減少が曲げ剛性の低下 を招くとモデル化した．そのため， $x=50 \pm 0.05 \mathrm{~mm}$ 部分のはり要素（図 13 の赤色のはり要素）の曲げ剛性を低 下させた. 図 13 の $x_{T 1} \sim x_{T 2}$ の範囲にある節点が超音波により加振され, $x_{R 1} \sim x_{R 2}$ の範囲にある節点から放出され た超音波が受信される．超音波による加振は $y$ 方向（せん断方向）のみとしモーメント加振は考えない. $x_{T 1}(\mathrm{~mm})$ を決定すると, 送受信機の幅 $h=10 \mathrm{~mm}$, 送受信機間のシフト量 $h_{S}(\mathrm{~mm})$, 送信波の入射角 $\theta$ から $x_{T 2}, x_{R 1}, x_{R 2}$ は以下 のように与えられる.

$$
\left(x_{T 2}, x_{R 1}, x_{R 2}\right)=\left(x_{T 1}+10 / \cos \theta, x_{T 1}+h_{S} / \cos \theta, x_{T 1}+\left(10+h_{S}\right) / \cos \theta\right) \quad(\mathrm{mm})
$$

実験での送信波はバースト波であるため, 数值計算では一定振幅の調和外力が作用すると考える. ただし, 図 13 に示寸ように超音波は試験片の垂直方向から $\theta$ 傾いて入射するため, 節点への加振力には送信機から試験片ま での距離の違いによる位相差が生じる. これを考慮すると, 任意の節点 $k$ に作用する $y$ 方向加振力 $q_{y, k}(t)$ は以下 のように表される. 式中の $x_{k}$ は節点 $k$ の $x$ 座標 $x_{k}=k L / n$ であり, 加振力は加振範囲 $x_{T 1} \sim x_{T 2}$ 内の節点のみに存在 する. $\omega$ は調和外力の角振動数, $c$ は空中音速, $i$ は虚数単位である.

$$
q_{y, k}(t)=Q_{y, k} \exp (i \omega t), \quad Q_{y, k}=\left\{\begin{array}{cc}
Q \exp \left[-\frac{i \omega\left(x_{k}-x_{T 1}\right)}{c} \sin \theta\right] & \left(x_{T 1} \leq x_{k} \leq x_{T 2}, \quad x_{k}=k L / n\right) \\
0 & (\text { others })
\end{array}\right.
$$

式(4)では位置 $x_{T 1}$ を基準に加振力の位相を定めた. 実験で使用したコントローラの出力から送信機の加振力は約 $1.3 \mathrm{~N}$ であり, この值を加振範囲内の節点数で等分して式(4)における調和外力の振幅 $Q$ とした. 加振振動数は実 験と同じ $\omega / 2 \pi=620 \mathrm{kHz}$ とした. 式(4)の加振力に対して $Y_{k}, \Phi_{k}$ を複素振幅として $y_{k}(t), \phi_{k}(t)$ を次のように表す.

$$
y_{k}(t)=Y_{k} \exp (i \omega t), \quad \phi_{k}(t)=\Phi_{k} \exp (i \omega t)
$$

複素振幅 $Y_{k}, \Phi_{k}$ は以下の複素連立 1 次方程式を解くことで求められる.

$$
\left(\boldsymbol{K}-\omega^{2} \boldsymbol{M}\right) \boldsymbol{Y}=\boldsymbol{Q}
$$

ここに, $k=(1, \cdots, n-1)$ として

$$
\begin{gathered}
\boldsymbol{Y}={ }^{t}\left[Y_{1}, \Phi_{1}, \cdots, Y_{n-1}, \Phi_{n-1}\right], \quad \boldsymbol{Q}={ }^{t}\left[Q_{y, 1}, Q_{\phi, 1}, \cdots, Q_{y, n-1}, Q_{\phi, n-1}\right], \quad Q_{\phi, k}=0 \\
\boldsymbol{M}=\operatorname{diag}\left(m_{1}, J_{1}, \cdots, m_{n-1}, J_{n-1}\right), \quad m_{k}=\rho \frac{L}{n} d w, \quad J_{k}=\frac{m_{k}}{12}\left[d^{2}+\left(\frac{L}{n}\right)^{2}\right]
\end{gathered}
$$

$$
\boldsymbol{K}=\left[\begin{array}{cccc}
\boldsymbol{A}_{1} & \boldsymbol{B}_{2} & & \mathbf{0} \\
{ }^{t} \boldsymbol{B}_{2} & \boldsymbol{A}_{2} & & \\
& & \ddots & \boldsymbol{B}_{n-1} \\
\mathbf{0} & & { }^{t} \boldsymbol{B}_{n-1} & \boldsymbol{A}_{n-1}
\end{array}\right], \quad \boldsymbol{A}_{k}=\frac{(1+i \eta) E I}{l^{3}}\left[\begin{array}{cc}
24 & 0 \\
0 & 8 l^{2}
\end{array}\right], \quad \boldsymbol{B}_{k}=\frac{(1+i \eta) E I}{l^{3}}\left[\begin{array}{cc}
-12 & 6 l \\
-6 l & 2 l^{2}
\end{array}\right], \quad l=\frac{L}{n}
$$

$m_{k}, J_{k}$ は節点 $k$ の質量, 慣性モーメント, $E I$ ははり要素の曲げ岡性である. モーメント加振は考慮しないため, その振幅を表す式(7)中の $Q_{\phi, k}$ は寸べて 0 となる. 式(7) (9)における具体的な值は 3.1 節で述べた值とした. この うちの曲げ剛性は，実験と同じ入射角 $\theta_{c}=37.5 \mathrm{deg}$.でシミュレーションにおいてもコインシデンス効果が起こる ように設定した值である.これにより, 実験と同一の幾何学的配置の下で数值シミュレーションの結果を実験結 果と比較する. また, はり要素には損失係数 $\eta$ の構造減衰を考慮しており, 実験で観測された減衰と合うように $\eta=0.1$ とした. モデルの分割数は $n=2 \times 10^{3}$ とした. 
受信される信号は，図 13 の $x_{R 1} \sim x_{R 2}$ の範囲にある節点から放出された超音波と考える. この範囲にある節点を 総称して節点 $k^{\prime}$ とし, 横方向の振動 $y_{k^{\prime}}(t)$ のみが超音波の投射に寄与すると考えると, 受信される音圧信号 $p(t)$ は, 空気の密度を $\rho_{A}$, 節点 $k^{\prime}$ と受信機との距離を $r_{k^{\prime}}$, 節点 $k^{\prime}$ の総数を $n_{k^{\prime}}$ として, 以下のように表される.

$$
p(t)=\frac{1}{n_{k^{\prime}}} \sum_{k^{\prime}} \rho_{A} c \omega Y_{k^{\prime}} \exp \left[i \omega\left(t-\frac{r_{k^{\prime}}}{c}\right)+\frac{i \pi}{2}\right]
$$

式(10)の指数部にある $i \pi / 2$ は，試験片の振動変位と音圧との間の位相差を示している.

\section{$4 \cdot 2$ コインシデンス効果の再現}

まず集中系モデルに瑕疪がない状態，すなわち，すべてのはり要素の曲げ岡性が同一の状態で，入射角度をコ インシデンス角度としてシミュレーションを行った．超音波による加振範囲は図 13 において $x_{T 1}=35.0 \mathrm{~mm}$ とす ると, $h_{S}=15 \mathrm{~mm}, \theta=\theta_{c}=37.5 \mathrm{deg}$. とした式(3)から $\left(x_{T 1}, x_{T 2}\right)=(35.0,47.6) \mathrm{mm}$ となる. 加振力の周期を $\tau$ として時刻 $t=0, \tau / 6$ および $2 \tau / 6$ での $y$ 方向変位 $\operatorname{Re}\left[y_{k}(t)\right]$ の $x$ 方向分布を図 14 に示寸. この分布は各時刻での試験片の横変位 であり，長手方向に曲げ波が生じている様相を表す．図 14(a)の薄赤色部分（Incident area）は加振範囲を示す. 加 振範囲では超音波の入射の向きに曲げ波が成長していることからコインシデンス効果の発生を確認できる. 加振 範囲を超えると曲げ波は減衰し $x=70 \mathrm{~mm}$ までにほぼ 0 になる. 一方，入射方向と逆向きの範囲 $x \leq x_{T 1}$ には曲げ波 は発生しない．また，図 14(a)の破線部を拡大した図 14(b)では，時刻が $t=0, \tau / 6,2 \tau / 6$ と進むにつれ曲げ波が $x$ の 正方向に進む様子が観察される。このように，コインシデンス効果では試験片上に一方向のみに進む曲げ波が発 生することを確認できる.


Fig. 14 Numerical results of oblique incidence of ultrasound at coincidence angle. Lateral displacements at $t=0, \tau / 6,2 \tau / 6$, where $\tau$ is one cycle of excitation, are plotted. (a) Wave motion is formed on heat seal sample. Amplitude increases in the incident area along the positive direction of $x$-coordinate. This is "coincidence effect". Decrease of amplitude is observed out of the incident area. No wave motion is found at $x<x_{T 1}$. (b) Enlarged figure of wave motion. Traveling wave of bending motion is clearly observed.

\section{$4 \cdot 3$ 提案手法の有効性の確認}

次に，モデルに瑕疪を設定して数值シミュレーションを行った．瑕疪部のはり要素の曲げ岡性を $\alpha E I(\alpha<1)$ に 低下させて瑕疵をモデル化し，実験においてピンホールによる受信波の位相遅れが最も大きかった図 7 の Case $\mathrm{A} 2$ を模擬した. そのため, 瑕疪部 $(x=50 \pm 0.05 \mathrm{~mm})$ が加振範囲の右側かつ受信範囲の左側にあるように $x_{T 1}=35.0$ $\mathrm{mm}$ として, 式(3)から加振範囲を $\left(x_{T 1}, x_{T 2}\right)=(35.0,47.6) \mathrm{mm}$, 受信範囲を $\left(x_{R 1}, x_{R 2}\right)=(53.9,66.5) \mathrm{mm}$ とした. 瑕疪部 の剛性低下を表す岡性低下率 $\alpha$ は $\alpha=0.5,0.3,0.1$ の 3 つ值とし, 瑕疪がない $\alpha=1.0$ も比較のため併せて用いた. なお，ここでは現象の定性的な理解を目的として，ピンホールを円柱状の欠損とした際の断面二次モーメントの 減少量よりも大きな剛性低下を与えている. 図 $15(\mathrm{a})$ は時刻 $t=0$ における $y$ 方向変位の実部 $\operatorname{Re}\left[y_{k}(0)\right]$ であり, 横 軸は試験片の $x$ 座標, 薄赤色および黄色の部分はそれぞれ加振範囲および受信範囲を表す. 加振範囲でコインシ デンス効果による曲げ波が発生し，加振範囲を出た直後に瑕疪部（Defect， $x=50 \pm 0.05 \mathrm{~mm}$ ）を通過する．瑕疪部 通過直後である図 $15(\mathrm{a})$ の破線部の拡大図を図 15(b)に示す．瑕疪がある波形（ $\alpha=0.5,0.3,0.1 ）$ は瑕疪がない波形

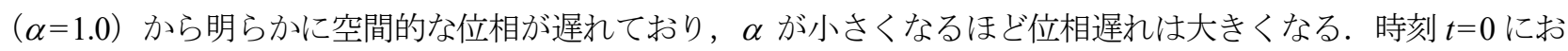
ける $y_{k}(0)$ の位相を $\tan ^{-1}\left[\operatorname{Im}\left(Y_{k}\right) / \operatorname{Re}\left(Y_{k}\right)\right]$ と表し, 瑕疪がない $\alpha=1.0$ の波形に対する $\alpha=0.5,0.3,0.1$ の波形の位相 差を図 15(c)に示す. 図 15(c)の横軸と網掛けは図 15(a) と同一である. 図 15(c)から， $y_{k}(0)$ の位相は瑕疵を通過し 
た直後に瑕疪がない場合に対して明らかな遅れを生じ， $\alpha$ が小さいほど遅れは大きくなる．また，位相遅れは $x$ 方向の伝播距離に関わらずほぼ一定值を保つ. 式(10)から計算した受信波の波形を図 15(d)に示すと， $\alpha$ が小さい ほど時間的な位相遅れが大きくなり実験と同様の結果が得られた。したがって，実験の受信波に現れた位相遅れ はピンホールによる試験片の局所的な剛性低下を効果的に捉えたものと思われる. なお，図 $15(\mathrm{c})$ に見られる瑕疵 部より手前の領域 $(x<50 \mathrm{~mm})$ で位相差が振動する現象は瑕疪部での曲げ波の反射によるものであり，この領域 では瑕疵による明確な位相の違いは見られない.

また，瑕疪の条件を変えずに別の周波数の超音波を投射するシミュレーションを行うと，周波数に応じた適切 な入射角でコインシデンス効果を発生させることにより, 図 15(c), (d)に見られるような位相遅れを得られる. 特 に, 実験よりも高い周波数の超音波を投射すると位相遅れが拡大寸ることがシミュレーションで得られており， 3.3 節で検出が難しかった小径ピンホールも検出可能になると期待される.

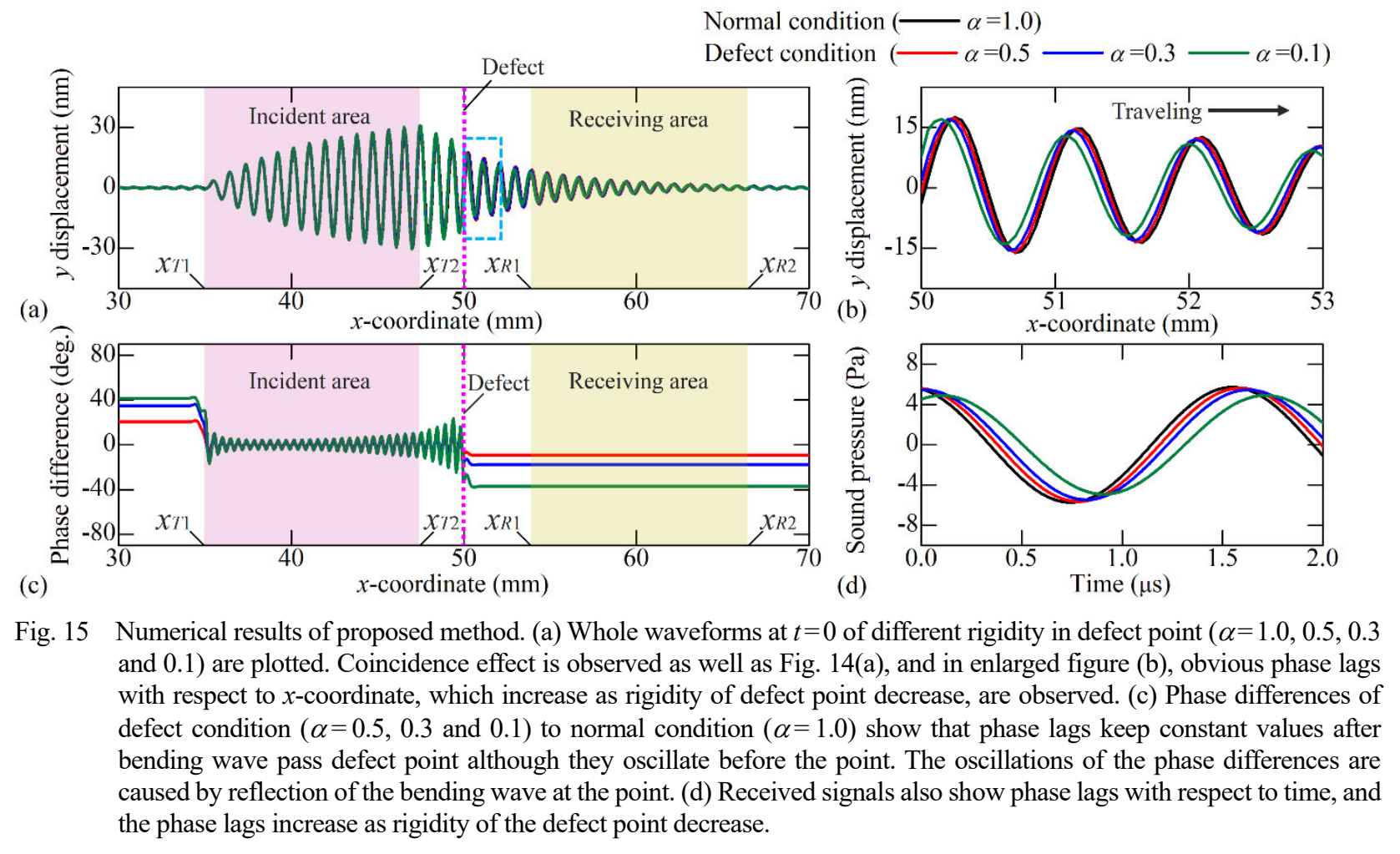

次に, 提案手法と同様に入射角度 $\theta$ をコインシデンス角度 $\theta_{c}=37.5 \mathrm{deg}$. とするものの, 送信機の正面で超音波を 受信する図 11(a)の検查法を模擬して数值シミュレーションを行った. 図 13 において $h_{S}=0 \mathrm{~mm}$ であり加振・受信 範囲は共通となる. その範囲の中央に瑕疪が位置するように $\left(x_{T 1}, x_{T 2}\right)=\left(x_{R 1}, x_{R 2}\right)=(43.7,56.3) \mathrm{mm}$ とした. 結果を図 15 と同様の形で図 16 に示寸. 加振・受信範囲は水色部分である. 図 16(a)では, 曲げ波は加振範囲で瑕疵部まで 成長し, 瑕疪部で一旦振幅が低下した後再びわずかに成長して加振範囲を出る. その後の減衰は図 15 と同様であ る. 図 16(b)の拡大図では, 琚疪通過後の位相差が徐々に小さくなる様子が見られる。この現象は図 16(c)に示寸 $y_{k}(0)$ 全体の位相差に端的に現れている. 明確な位相遅れは瑕疪通過後のわずかな領域のみであり, 曲げ波の進 行につれ各位相差は小さくなっていく.また, 図 16(d)の受信信号でも瑕疵による位相遅れは小さく, 図 11 の実 験結果を定性的に再現している。このような挙動が生じる理由は曲げ波が瑕疪通過後も加振領域内にあるため継 続的に強制加振されることにある. コインシデンス角度での超音波投射では，2 章に示したように加振力（空中 超音波による粗密波）のヒートシールフィルムに沿った移動速度は瑕疪がない場合の曲げ波の伝播速度に等しく なる，そのため，加振力は瑕疪による位相遅れを戻す向きに作用し，図 16(c)の瑕疵通過直後は図 $15(\mathrm{c})$ と同様の 位相遅れがあるものの，瑕疪のない場合の位相に近づいていく。これにより受信波形図 16(d)にも図 15(d)ほどの 位相遅れは観測されない. したがって, コインシデンス効果を発生させても, 図 11(a)のように送信機の正面で受 
信波を測定すると効果的な瑕疪検出が行えないことがわかる.これに対し図 15 では, 瑕疪を通過した後の曲げ波 は強制加振されないため，一度発生した位相差が保持される。この性質により，提案手法では効果的な瑕疪検出 が実現できる.

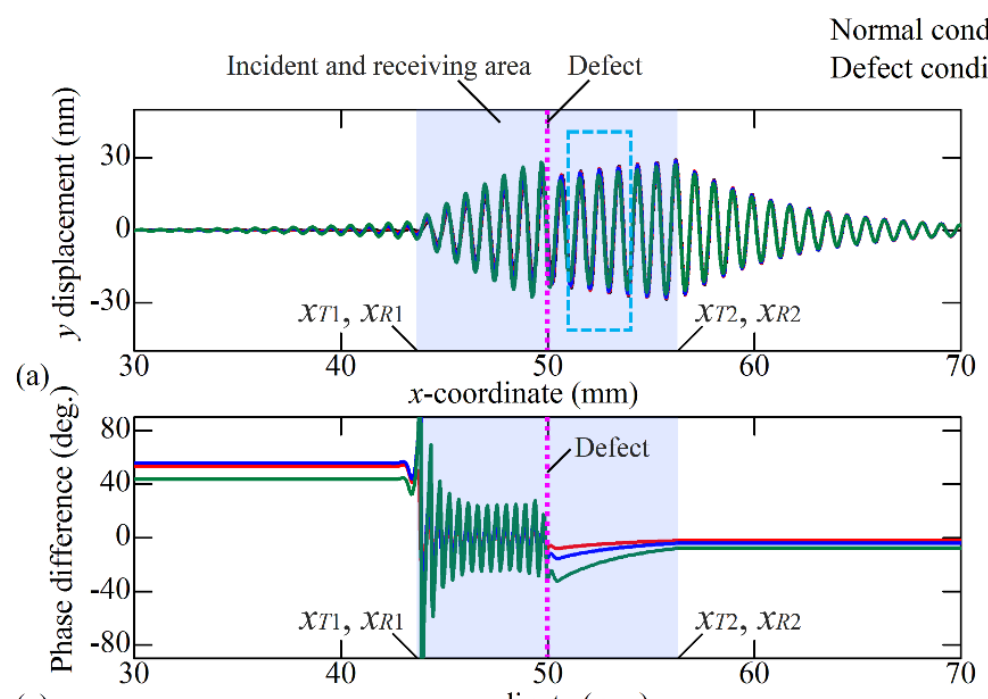

(c)

$x$-coordinate $(\mathrm{mm})$

0 (b)


(d)

Time $(\mu s)$

Fig. 16 Numerical results of the arrangement of Fig. 11(a) in the same manner as Fig. 15. (a) Amplitudes of bending wave grow until defect point, and decreases at the point. Amplitudes slightly grow again after the defect point during incident and receiving area. In enlarged figure (b), phase lags due to defect conditions gradually return to normal condition as the waves move to right-hand side, and figure (c) specifically demonstrates these phenomena, phase lags gradually return to zero during excitation area. Before the defect point, the phase differences oscillate because the bending wave is reflected at the point as with Fig. 15. (d) Received signals also show phase lags with respect to time, however, these lags are smaller than the ones in Fig. 15(d).

最後に，試験片に垂直に超音波を投射する図 10(a)を模擬して数值シミュレーションを行った．図 13 において $\theta=0$ deg., $h_{S}=0 \mathrm{~mm}$ とし, 加振・受信範囲の中央に瑕疵が位置するように $\left(x_{T 1}, x_{T 2}\right)=\left(x_{R 1}, x_{R 2}\right)=(45.0,55.0) \mathrm{mm}$ とし た. 瑕疪なし $(\alpha=1.0)$ の時刻 $t=0, \tau / 6,2 \tau / 6$ における曲げ波形状 $\operatorname{Re}\left[y_{k}(t)\right]$ を図 17(a)に示す. 垂直投射では, 試験 片の振動は超音波が入射寸る領域のみにほぼ限られ，コインシデンス効果で見られた曲げ波の進行波は発生しな い. 図 17(b)には, $\alpha=1.0$ に加え，瑕疵部の剛性低下率 $\alpha=0.5,0.3,0.1$ に対寸る時刻 $t=0$ での振動形状 $\operatorname{Re}\left[y_{k}(0)\right]$ を示す. $\alpha$ の変化に対して振動形状はまったく変化せず，すべてのプロットは重なっている. すなわち，瑕疪に より試験片の振動はほとんど影響を受けないことがわかる.そのため,受信信号にも瑕疵による影響は現れない. このことは，超音波の投射範囲における瑕疪の有無に関わらず受信波に位相差がほとんど現れなかった図 10(b) の実験結果を裏付けている. 試験片に超音波を垂直投射する検査法では瑕疪を検出できないことが実験に加え数 值的にも示された.


Fig. 17 Numerical results of vertical incidence of ultrasound shown in Fig. 10(a). (a) Lateral displacements at $t=0, \tau / 6,2 \tau / 6$, where $\tau$ is one cycle of excitation. Only the incident area shows substantial lateral vibration. Traveling wave along $x$ coordinate does not appear. (b) Waveforms at $t=0$ for different rigidity of defect point $(\alpha=1.0,0.5,0.3$ and 0.1$)$. No difference pertaining to change of the rigidity is found. 


\section{5. 結 言}

空中超音波のコインシデンス効果を利用するヒートシール瑕疪の非接触検出手法を提案した．提案手法では， コインシデンス効果により検查対象に曲げ波の進行波を励起させ，超音波受信機を送信機から曲げ波の進行方向 に離した位置に配置して透過超音波を受信した．ピンホールを模擬した試験片に対する実験から，送信機と受信 機の間にピンホールがある場合に受信波の位相に大きな遅れを観測し，ピンホールの存在を検出できた，一方， コインシデンス効果を発生させるものの, 受信機を送信機の正面に配置した場合には位相の遅れ量が低下して検 出感度が鈍化した．また，コインシデンス効果が生じない空中超音波の垂直投射の場合には，まったくピンホー ルを検出できなかった。これらの実験結果から提案手法の有効性が確認された. さらに, 瑕疵部でヒートシール の剛性が低下すると仮定してヒートシール試験片をモデル化し, 超音波による強制振動として実験を模擬した数 値シミュレーションを行った. シミュレーション結果は実験結果を十分に再現するものであり, 提案手法の有効 性を数值的にも裏付けた.

\section{文献}

Axelson, L. and Cavlin, S., Aseptic integrity and microhole determination of packages by gas leakage detection, Packaging Technology and Science, Vol.4, No.1 (1991), pp.9-20.

Axelson, L., Cavlin, S. and Nordström, J., Aseptic integrity and microhole determination of packages by electrolytic conductance measurement, Packaging Technology and Science, Vol.3, No.3 (1990), pp.141-162.

Ayhan, Z. and Zhang, Q.H., Evaluation of heat seal quality of aseptic food containers by ultrasonic and optical microscopic imaging, European Food Research and Technology, Vol.217, No.4(2003), pp.365-368.

Barnes, M., Dudbridge, M. and Duckett, T., Polarised light stress analysis and laser scatter imaging for non-contact inspection of heat seals in food trays, Journal of Food Engineering, Vol.112, No.3 (2012), pp.183-190.

Cremer, L., Theorie der schalldämmung dünner wände bei schrägem einfall (Theory of the sound attenuation of thin walls with oblique incidence), Akustische Zeitschrift, Vol.7 (1942), pp.81-104.

D'huys, K., Saeys, W. and De Ketelaere, B., Active infrared thermography for seal contamination detection in heat-sealed food packaging, Journal of Imaging, Vol.2, No.4 (2016), DOI:doi.org/10.3390/jimaging2040033.

Hsu, C.L. and Chang, K.S., Development of a novel method for detecting the integrity of aseptic paperboard laminate packages containing aluminium foil, Food Control, Vol.18, No.2 (2007), pp.102-107.

Larsson, L.A., Hurme, E., Cavlin, S. and Ahvenainen, R., Leakage analysis of packages by the electrolytic test, Packaging Technology and Science, Vol.10, No.4 (1997), pp.209-220.

森田康之, Adrian, D., 大谷知行, 川瀬晃道，テラヘルツ波を用いたフレキシブルパッケージに生じる微小欠陥の 実時間検出，日本機械学会論文集 C 編，Vol.71, No.706 (2005), pp.1999-2005.

Ozguler, A., Morris, S. A. and O'Brien, W.D., Ultrasonic imaging of micro-leaks and seal contamination in flexible food packages by the pulse-echo technique, Journal of Food Science, Vol.63, No.4 (1998), pp.673-678.

Pascall, M.A., Richtsmeier, J., Riemer, J. and Farahbakhsh, B., Non-destructive packaging seal strength analysis and leak detection using ultrasonic imaging, Packaging Technology and Science, Vol.15, No.6 (2002), pp.275-285.

Song, Y.S., Gera, M., Jain, B. and Koontz, J.L., Evaluation of a non-destructive high-voltage technique for the detection of pinhole leaks in flexible and semi-rigid packages for foods, Packaging and Technology and Science, Vol.27, No.6 (2014), pp.423-436.

玉井裕, 高萩敏男, 中井幹雄, 有限平板のコインシデンス効果に関する研究, 日本機会学会論文集 C 編, Vol.53, No.491 (1987), pp.1435-1442.

社団法人高分子学会編，高分子データ・ハンドブック一応用編一 (1986), p.21.

\section{References}

Axelson, L. and Cavlin, S., Aseptic integrity and microhole determination of packages by gas leakage detection, Packaging Technology and Science, Vol.4, No.1 (1991), pp.9-20.

Axelson, L., Cavlin, S. and Nordström, J., Aseptic integrity and microhole determination of packages by electrolytic conductance measurement, Packaging Technology and Science, Vol.3, No.3 (1990), pp.141-162.

Ayhan, Z. and Zhang, Q.H., Evaluation of heat seal quality of aseptic food containers by ultrasonic and optical microscopic 
imaging, European Food Research and Technology, Vol.217, No.4(2003), pp.365-368.

Barnes, M., Dudbridge, M. and Duckett, T., Polarised light stress analysis and laser scatter imaging for non-contact inspection of heat seals in food trays, Journal of Food Engineering, Vol.112, No.3 (2012), pp.183-190.

Cremer, L., Theorie der schalldämmung dünner wände bei schrägem einfall (Theory of the sound attenuation of thin walls with oblique incidence), Akustische Zeitschrift, Vol.7 (1942), pp.81-104.

D'huys, K., Saeys, W. and De Ketelaere, B., Active infrared thermography for seal contamination detection in heat-sealed food packaging, Journal of Imaging, Vol.2, No.4 (2016), DOI:doi.org/10.3390/jimaging2040033.

Hsu, C. L. and Chang, K. S., Development of a novel method for detecting the integrity of aseptic paperboard laminate packages containing aluminium foil, Food Control, Vol.18, No.2 (2007), pp.102-107.

Larsson, L. A., Hurme, E., Cavlin, S. and Ahvenainen, R., Leakage analysis of packages by the electrolytic test, Packaging Technology and Science, Vol.10, No.4 (1997), pp.209-220.

Morita, Y., Adrian, D., Otani, C. and Kawase, K., Real-time inspection using a terahertz technique to detect micro-leak defects in the seal of flexible plastic packages, Transactions of the Japan Society of Mechanical Engineers, Series C, Vol.71, No.706 (2005), pp.1999-2005 (in Japanese).

Ozguler, A., Morris, S. A. and O’Brien, W. D., Ultrasonic imaging of micro-leaks and seal contamination in flexible food packages by the pulse-echo technique, Journal of Food Science, Vol.63, No.4 (1998), pp.673-678.

Pascall, M. A., Richtsmeier, J., Riemer, J. and Farahbakhsh, B., Non-destructive packaging seal strength analysis and leak detection using ultrasonic imaging, Packaging Technology and Science, Vol.15, No.6 (2002), pp.275-285.

Song, Y. S., Gera, M., Jain, B. and Koontz, J. L., Evaluation of a non-destructive high-voltage technique for the detection of pinhole leaks in flexible and semi-rigid packages for foods, Packaging and Technology and Science, Vol.27, No.6 (2014), pp.423-436.

Tamai, Y., Takahagi, T. and Nakai, M., Coincidence effect of a finite plate, Transactions of the Japan Society of Mechanical Engineers, Series C, Vol.53, No.491 (1987), pp.1435-1442 (in Japanese).

The Society of Polymer Science ed., KOUBUNSHI Data Handbook — application — (1986), p.21 (in Japanese). 